\title{
Imágenes de Hungría. Registro visual e investigación etnográfica en Hungría
}

NOÉMI ALEXA

Departamento Antropología Cultural Universidad Eötvös Loránd, Budapest
Blai GuARNÉ

Departamento Antropología Social Universidad de Barcelona

\section{PUNTO DE PARTIDA}

En este artículo ${ }^{1}$ trazaremos un recorrido a través de la relación entre el registro audiovisual y la investigación etnográfica en Hungría, desde las primeras noticias que se recogieron en la prensa sobre la aparición de la fotografía como invento, hasta el papel de los principales estilos fotográficos originales, no tanto desde una perspectiva estética, sino por su valor como ejercicio autorreflexivo, que los intelectuales húngaros, fotógrafos, sociólogos y etnógrafos, han realizado sobre sí mismos y su propia realidad nacional. En este recorrido consideraremos el papel del Museo Etnográfico de Budapest, auténtico motor durante décadas de la investigación audiovisual en Hungría, y cuyos fondos documentales constituyen en la actualidad una fuente de datos imprescindible para el estudio etnográfico $^{2}$ de este país. El análisis de la aparición del film de carácter

1 Nuestro agradecimiento al Dr. Lajos Boglár, del Departamento de Antropología Cultural de la Universidad Eötvös Loránd de Budapest; al Néprajzi Múzeum (Museo Etnográfico) de Budapest y, muy especialmente, a su director el Dr. Tamás Hofer. También, al profesor János Tari y a la profesora Judit Csorba, a la Magyar Tudományos Akadémia (Academia Húngara de Ciencias) y, en especial, al Dr. Sárkány; y al profesor András Bán, del Departamento de Antropología Visual y Cultural de la Universidad de Miskolc.

2 Los registros de audio merecerían un capítulo aparte, más extenso que el que nos ocupa. Por ejemplo, sobre la labor de Béla Bartók - en el contexto del movimiento romántico en la música europea- de recuperación y reinterpretación del folklore musical nacional, y sus vínculos con la incipiente investigación etnográfica moderna. Capítulo en el que deberíamos considerar la labor archivística de registros sonoros, canciones y danzas que realiza el Instituto de Musicología Béla Bartók, fundado por su discípulo Zoltán Kodály en la Academia Húngara de Ciencias, y a cuyo Instituto y en especial al Dr. László Felföldi, director del Departamento de Danzas Folklóricas, agradecemos su amable colaboración intelectual. Digno de otro estudio sería también el papel de los archivos fotográficos, que en gran número existen en 
antropológico en el contexto investigador húngaro y las últimas investigaciones audiovisuales llevadas a cabo en los centros universitarios de Miskolc y Budapest cerrarán el artículo.

LAS PRIMERAS IMÁGENES, LAS PRIMERAS MIRADAS

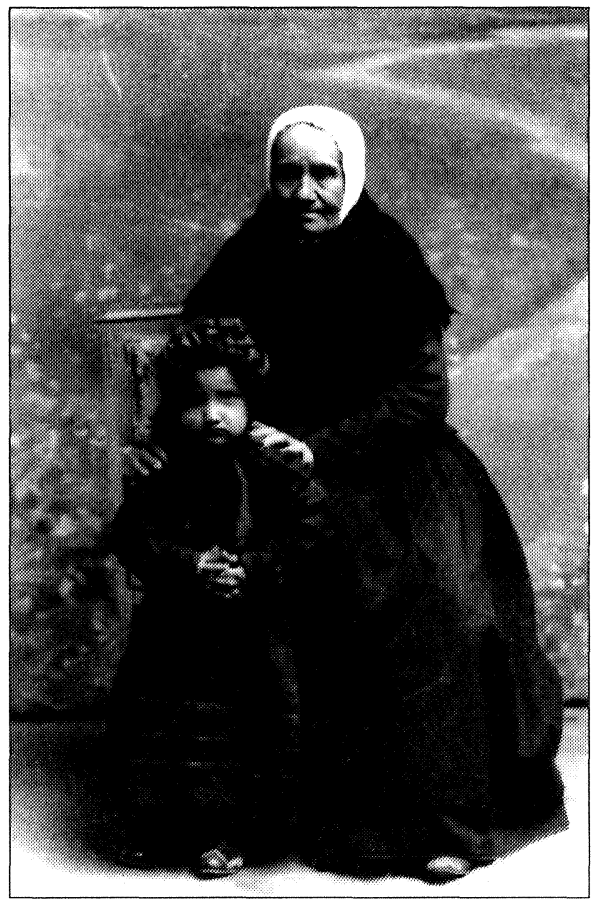

El 2 de febrero de 1839 el periódico húngaro Hasznos Mulatságok publica la noticia de un sensacional descubrimiento ${ }^{3}$ realizado en Francia por un científico llamado Daguerre, una máquina capaz de fijar la expresión facial como si de un espejo perfecto se tratase. El 8 de junio de 1840 el público de la todavía Pest contempla fascinado el invento ${ }^{4}$ en una exhibición popular. Dos meses más tarde, el 20 de agosto, Antal Vállas (1809-1868) se convierte, seguramente, en el primer fotógrafo de la historia de Hungría, al tomar un daguerrotipo en una sesión de la Academia Húngara de Ciencias.

Durante toda la década de los cuarenta del siglo pasado un gran

toda Hungría, como es el caso del archivo de imágenes del Testnevelési és Sportmúzeum (Museo de Educación Física y Deporte) de Budapest, a cuyo director, Szabó Lajos, agradecemos las facilidades prestadas en su consulta.

3 Los primeros nombres con los que se conoció la invención de la fotografía en Hungría fueron "fényírászat", escritura de luz, acuñado por Antal Simonyi, o "fényképelés", imágenes de huz, de Bertalan Székely y Milkós Barabás.

¿ La fascinación que despertó el invento de la fotografía convulsionó toda la sociedad. Los tres primeros daguerrotipos de la historia de Hungría fueron tomados en Viena por György Apponyi, Embajador Imperial, que los presentó al Ministro Metternich y al Emperardor. La Familia Real y Metternich, entusiastas de la fotografía, enviaron al profesor Ettingshausen a visitar a Daguerre en París. El físico estudió los límites de la técnica aplicada y sugirió una mejora óptica, recomendando a su Majestad las investigaciones de su colega József Petzvál que, en 1846, publicaría un tratado sobre lentes y fotografía. 
número de daguerrotipistas se lanzó a la calle con la intención de tomar imágenes de Pest y otras ciudades. Húngaros e inmigrantes, como el italiano Giacomo Marastoni, hungarizado como Jakab Marastoni; joyeros como Lajos Kawalky, o Lipót Strelisky; pintores como József Heller, o químicos e ingenieros como Antal Simonyi se rindieron a la seduccion de las posibilidades del nuevo arte.

Desde la década de 1850 el número de fotógrafos se incrementa con las oportunidades económicas del negocio. Y en paralelo al interés social, estos pioneros de la fotografía húngara fueron inventando distintas ideas para ganarse a todos los públicos. Ya en 1856 Antal Oszwald vendía fotografías estereoscópicas en su tienda de la calle Nádor. György Klösz instaló una cámara oscura encima de una carreta y se dedicó a fotografiar las calles y plazas de la nueva Budapest. Mientras tanto, Károly Divald recorría los montes Tatra durante el verano, tomando imágenes que luego vendía como postales en paradas turísticas y en la óptica Calderoni de la misma ciudad.

Pintores de renombre como Munkácsy vieron en la fotografía una nueva materia prima, y tomaron imágenes para sus grandes obras — - La celda de los condenados", "Árpád y la conquista de Hungría" - con el propósito de captar el "enorme realismo" que solo la fotografia podía proporcionar. La aparición de la fotografía conmocionó tanto el panorama artístico y social que, mientras Munkácsy construía sus cuadros como en un daguerrotipo, retratistas como Miklós Barabás, József Borsos, Albert Doctor, Ede Alkér, Béla Vízkeleti, o Ede Pesky asistían poco a poco a la perdida de su clientela, viéndose obligados a abrir estudios fotográficos en una especie de reconversión profesional ${ }^{5}$.

Desde las dos últimas décadas del siglo XIx la fotografia supuso para la clase media húngara la forma más atractiva de mostrar su estatus social. En este contexto de renovación, Heinrich Kühn, Johannes Watzek y Hugo Henneberg en Viena, o Robert Demachy y Emile-Joachim-Constant Puyo en París, introducen el pictorialismo. Se convierte, así, el estilo pictórico en el principal y más potente en la mirada fotográfica de finales de siglo ${ }^{6}$.

En Hungría, el pictorialismo cobra aceptación en el cambio de siglo con nombres como Mihály Eszterházy, Dezsõ Feledi, József Pécsi, Dénes Rónai, István Kerny y Jószef Schermann en Budapest, o Jacques Faix y

\footnotetext{
5 Un elemento más de modernidad, que nos reafirma a la fotografía como la primera de las artes industriales, más cercana al siglo xx que al xIx.

6 Con representantes como Jenõ Gothard y Miklós Konkoly-Thege, Barón Loránd Eötvös, Lajos Lóczy o Ferenc Hopp.
} 
Márton Matusik en Arad; auténticos profesionales de la fotografía vinculados a las incipientes sociedades y círculos fotográficos.

Habría que esperar hasta el nuevo siglo para que los decorados, los telones, las columnas o las estatuas de papel maché empezasen a desaparecer de los encuadres, a la vez que las imágenes se volvían cada vez menos rígidas. En Hungría, y siguiendo los principios de Rudolf Dührkoop, Aladár Székely y Olga Máté intentaron incluso fotografiar modelos en movimiento, rodeados de objetos cotidianos.

Estamos en la mitad de la década de 1860 y el número de profesionales y amateurs de la fotografía registrados en Hungría alcanza ya los 281. Y esta cifra se incrementará hasta los 257 fotógrafos censados en 1882.

Frente a estos profesionales, los entusiastas amateurs habían creado un nuevo sistema artístico y estético sustancialmente distinto, con sus propias asociaciones como la Sociedad Húngara de Fotografía Amateur (1898), o la Sociedad Nacional de Fotógrafos Amateurs de Hungría ${ }^{7}$. Paralelamente, los fotógrafos profesionales constituirán el 5 de enero de 1906 la Sociedad Húngara de Fotógrafos Profesionales ${ }^{8}$. En 1908 existían ya en Hungría cinco asociaciones de fotografía amateur que participaron activamente en la primera Exhibición Nacional de Fotografía. El público de Budapest pudo contemplar en aquella ocasión más de mil imágenes expuestas en las doce salas de la muestra. Dos años más tarde, en 1910, la Exhibición Internacional sería visitada por tres mil personas.

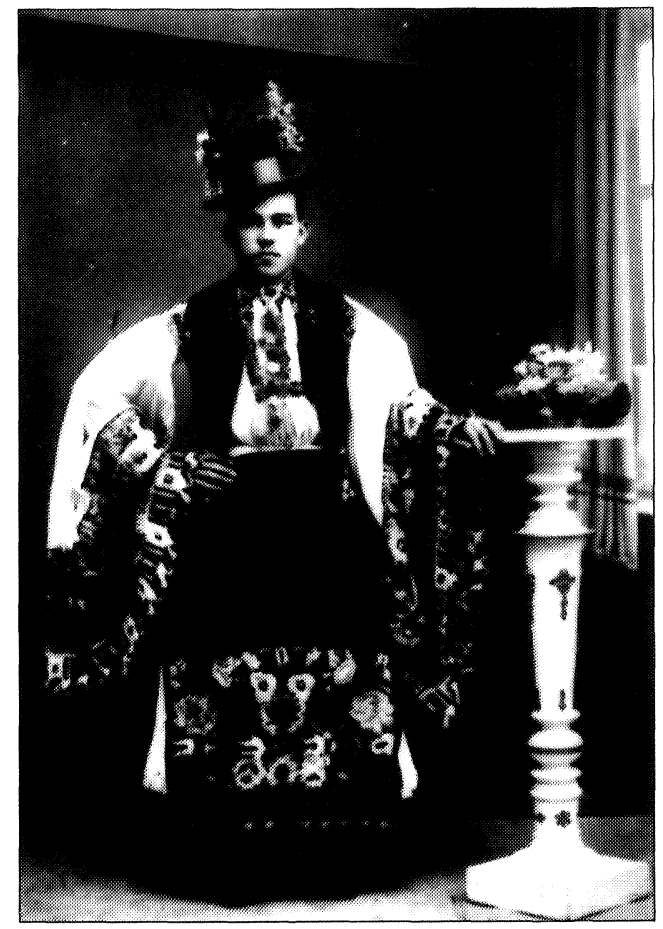

El número de fotógrafos amateurs ascendía en 1919 a la increíble cifra de 19.000 y se calcula un número de 210.000 cámaras a principios de

7 Fundada por el Dr. Artur Kohlmann, Andor Komoróczy y Zoltán Révész, y que, en 1907 , organizaba ya su primera exposición.

8 En torno a las figuras de Ödön Uher como presidente, y György Klösz y Mór Erdéli como vicepresidentes. 
la década de los treinta. En este contexto de efervescencia creativa surge la primera escuela fotográfica que podemos considerar propiamente húngara, el llamado "estilo húngaro".

LA PROPIA MIRADA. EL "ESTILO HÚNGARO»

¿Quedémonos en casa, busquemos y encontremos temas con los que se nos pueda reconocer en el extranjero, creemos la fotografía artística büngara con aire büngaro y cielo despejado búngaro! Rudolf Balogh, 1914? .

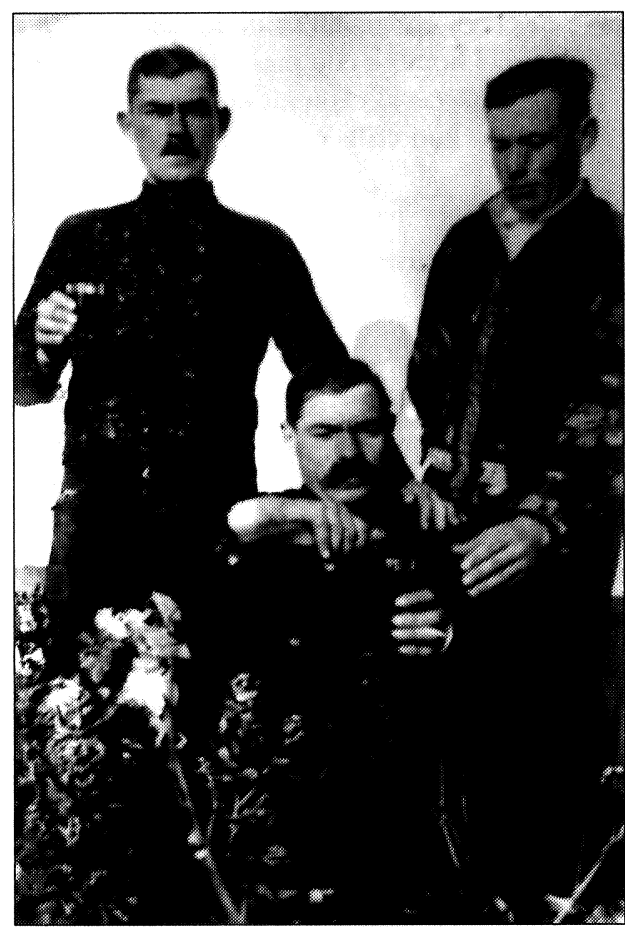

Desde un punto de vista antropológico y etnográfico el "estilo húngaro" resulta interesante, no tanto por la temática de sus imágenes, ni por las soluciones artísticas y técnicas que comportó, sino por ser el primer ejercicio autorreflexivo que los realizadores e intelectuales húngaros, pintores, fotógrafos, etnógrafos, tuvieron hacia sí mismos y su realidad nacional en este siglo, por ser, en definitiva, la primera expresión de su propia mirada.

Aún siendo un movimiento artístico iniciado por amateurs, la mayoría de los fotógrafos profesionales de estudio recibieron la influencia del "estilo húngaro" y, salvo en algunos sociofotógrafos y reporteros de prensa gráfica, su impronta estuvo presente hasta la década de los años cincuenta. Las obras de esta corriente se caracterizan por una atmósfera fácilmente reconocible. Sujetos tratados con virtuosismo en armoniosas composiciones que renuncian a reflejar el movimiento y en las que se tiene más en cuenta la contención formal que la verdad de la propia expresión.

9 «Maradjunk itthon, keressünk és találjunk olyan sujet-eket, amelyekkel külföldön jobban érvényesülhetünk - magyar mûvészi fényképezést teremtsünk, magyar levegõvel, derûs magyar éggel!» Rudolf BALOGH, "Az olvasóhoz (beköszöntõ)n, Fotómûvészet, 1914. 
En palabras de István Hevesi, el estilo húngaro es la expresión fotográfica de la vida, eentendida como muestra de moderación, prudencia y evasión de los más hondos o más conmovedores efectos" (Tõry 1989: 154).

Las obras de Rudolf Balogh, auténtico pionero y máximo teórico del "estilo húngaro", cambiaron la mirada de sus colegas durante décadas. Rendidos a la seducción de las posibilidades del tratamiento de la luz, indentificaron como el objetivo último de sus obras la materialización de los contrastes de luces y sombras:

La propuesta actual de la fotografía artística es la creación de imágenes claras, distintas a las composiciones pictóricas, que rompan con la imitación de la fotografía tradicional [...] los fotógrafos actuales ven el sol en sus miles de tonalidades, ven relucir el agua, el movimiento, la máquina y el hombre con otra mirada. Su mirada es libre y fotográfica, construyendo juegos realistas al capturar la luz de un modo como ninguna otra de las artes puede hacerlo (Rudolf Balogh, en Tõry 1989: 155).

La fotografía, entendida como el "arte de la luz", en palabras de Jenõ Dulovits, debe satisfacer, desde la autocontención estética, nuestro sentido de la belleza, ignorando la miseria plebs ${ }^{10}$.

Las fotografías de los representantes del "estilo húngaro" descubrieron una Hungría étnica, con temas propios de la vida campesina en la gran llanura y las tierras bajas. Sus realizaciones perseguían encontrar aquéllos que consideraban habían de ser los auténticos sujetos de la fotografía húngara: la llanura y sus hombres y mujeres magiares. Fue así como estos autores ${ }^{11}$ nos legaron imágenes de personajes, vestidos con trajes folklóricos, en fiestas o acartonadas rutinas cotidianas, en paisajes de luz brillante y cielos de nubes lanosas. Esta nostálgica actitud por un idílico pasado nacional debe entenderse desde una clave política y social, como reacción nacionalista al Tratado del Trianón y sus consecuencias ${ }^{12}$. Su des-

10 Para más información remitimos a los testimonios de István Hevesi, Rudolf Balogh, Jenõ Dulovits, en el muy interesante artículo de Tõry 1989.

11 Autores como Rudolf Balogh, Ernõ Vadas, Gyula Ramhab, Tibor Csörgõ, Frigyes Haller, István Kerny, Tibor Rehák, Lajos Hollán, Ferenc Aszmann, János Kunszt, János Sztály, Iván Vydarény, Imre Kinszki, Tibor Hegyei, Ferenc Csík, József Németh, Lajos Szabó, algunos de los cuales mostraron cierto inconformismo en la temática de sus obras e incluso, en algunos casos, apuntaron soluciones de síntesis entre el estilo al que se habían entregado y una mirada más vanguardista.

12 "No debemos menospreciar a aquellos fotógrafos que principalmente se interesaron por las imágenes del espectáculo [...] Durante los decenios de la miseria también había momentos hermosos, divertidos y festivos, si éstos no hubiesen existido el pueblo no habría podido sobrevivir a aquel mundo. Algunos fotógrafos se concentraron en tomar imágenes de los instantes poéticos de las fiestas o de la vida cotidiana. Sin su testimonio seríamos más pobres y la imagen de la época quedaría distorsionada” (Miklós 1989). 
precio por la atmósfera de las ciudades y lo que entendían como su falso internacionalismo, contrasta con la cándida mirada que de la vida campesina ofrecen. No hay muestras de sufrimiento, ni dolor o conflicto social en sus obras, que terminan por adolecer de una deliberada ignorancia ante el trabajo extenuante, o las míseras condiciones de la vida real. Imágenes distorsionadas que desprecian el rol social de la fotografía en beneficio de composiciones formalmente excelentes $y$, en última instancia, tan teatrales como las propias del pictorialismo europeo.

Contemplar actualmente algunas de estas imágenes con su sofisticada rigidez compositiva, su obsesiva búsqueda de la belleza ideal campesina, metonímicamente nacional, y sobre todo, su absoluto desprecio por cualquier realismo social contemporáneo, nos produce una extraña sensación de sorpresa y lejanía ante una mirada que empezó a morir con la llegada de la fotografía social y del periodismo gráfico.

LA MIRADA CONSCIENTE. LA FOTOGRAFÍA DE ORIENTACIÓN SOCIAL

La forma más refinada del registro fotográfico es la sociofotografía, reportaje de la sociedad bumana. Iván Hevesy, $1934^{13}$.

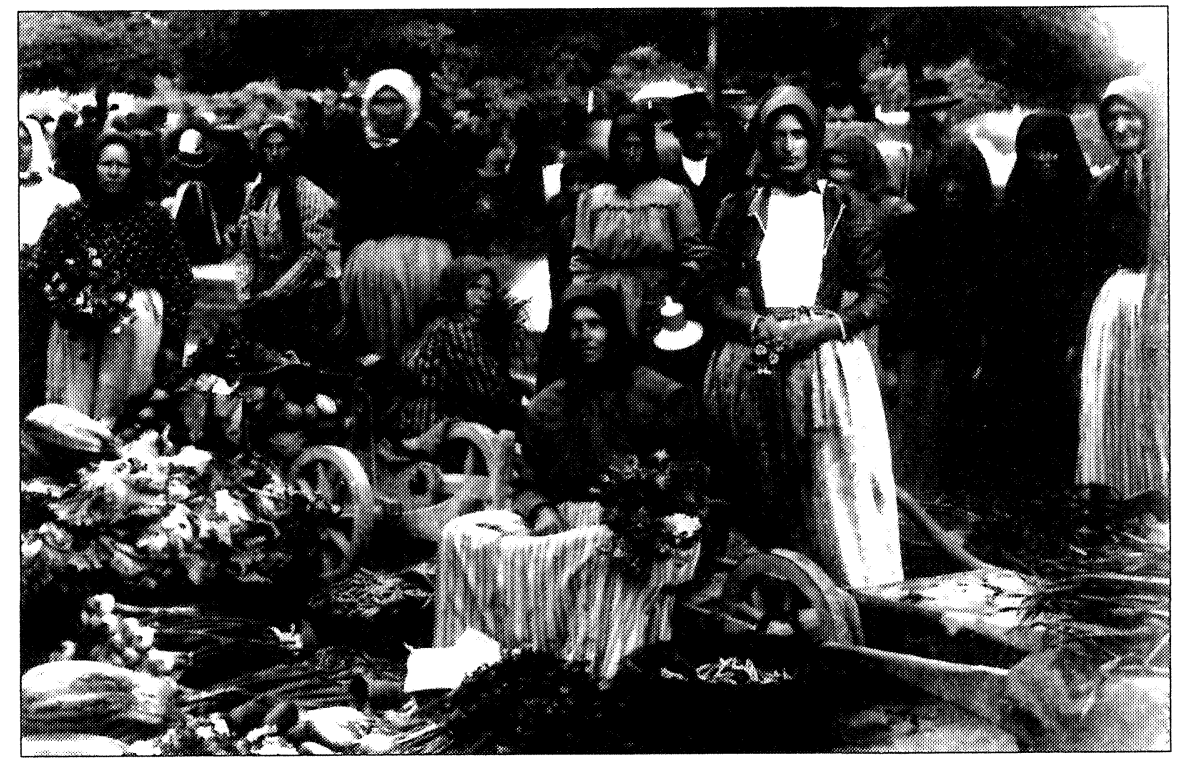

13 Iván Hevesy, A mûvészi riportfotó legmagasabb rendî alakja: a szociofotó, riportázs az emberi társadalomról (Budapest, 1934) (en Béla 1989: 280). 
La publicación impresa de la fotografía y por tanto su difusión masiva marcará, en los círculos intelectuales húngaros, un antes y un después en su propia mirada nacional. Cronológicamente podemos situar en la Hungría de principios del 1900 la publicación de las primeras fotografías en un medio de comunicación, y más concretamente de las imágenes de Ferenc Kiss en el dominical Vasárnapi Újság ${ }^{14}$.

No será, sin embargo, hasta la década de los treinta cuando la fotografía de orientación social cobre entidad como corriente estética, en torno a la figura de Lajos Kassák y el círculo de artistas e intelectuales de su periódico Munka (Trabajo). Serán los años dorados de la fotografía documental húngara. Los fotógrafos del Grupo Munka tomarán partido con sus imágenes y, siempre desde una mirada crítica y comprometida con los perdedores del sistema, denunciarán la realidad social por la que atravesaba el país ${ }^{15}$.

Todos ellos ${ }^{16}$ mantendrán a lo largo de sus trayectorias artísticas y vitales una estrecha relación con los movimientos socialdemócrata y comunista. Como ejemplo, basta citar los testimonios personales ${ }^{17}$ de Tibor Bass, miembro activo del Grupo Munka, del poeta Emil Gyagyovszky, de Dezsõ Révai —que participó con su cámara en la Guerra Civil Española-, de Kata Sugár y la Asociación de Artistas Socialistas, de Árpád Szélpál, cuyas

14 A la publicación de las fotografías de Kiss, seguirán los trabajos de T. Stayevski y $\mathrm{H}$. Kovatchev, de origen búlgaro, en la década de los años veinte, y el álbum publicado en Viena por Anton y Hans Bock. La fotografía húngara estableció sus primeros contactos internacionales desde finales de la década de los veinte y durante toda la de los treinta, principalmente en los límites de la monarquía. Podemos comprobar las simpatías austríacas por la fotografía social húngara, expresadas en los artículos de Der Kuckuck y Arbeiter Zeitung. La posterior inclusión de los fotógrafos húngaros en la corriente europea vendrá motivada por los contactos con la fotografía social alemana, la cooperación con fotógrafos de prensa soviéticos y el trabajo en el extranjero de fotógrafos de origen húngaro.

15 A menudo la fotografía social ha suscitado el temor del Sistema. Varios miembros del Grupo Munka estuvieron bajo constante amenza de arresto en la década de los veinte y treinta. La policía les censuró catálogos y prohibió exhibiciones como la de 1932 y Lajos Kassák, Lajos Lengyel, Lajos Tabák y Árpád Szélpál estuvieron en la cárcel por sus imágenes.

16 Miembros como Teréz Bergmann, Sándor Bodon, László Bruck, Sándor Frühof (Gönci), Ferenc Haár, Zsuzsa Kovács (Anna Schmidt), Lajos Lengyel, Ernõ Schubert y Lajos Tabák, Tibor Bass. Y otros representantes de la fotografía social húngara, como Kata Kálmán, Kata Sugár y Dezsõ Révai, Kálmán Brodyáni, László Roth (Rath), Iván Hevesy, o Rezsõ Szalantai.

17 O de tantos otros, como los de Lajos Ladányi, Klára Langer, Ernõ Marton (Preisz) y su obra en pintura y escultura; Éva Besnyõ y su obra en Berlín y Holanda, o Ilka Révai que organizó un círculo fotográfico para trabajadores. 
imágenes se publicaban en el diario Népszava, o Károly Escher que trabajó para el suplemento gráfico de Pesti Napló.

Desconocemos todavía la trayectoria de muchos realizadores en este período de la historia de la fotografía social húngara y tenemos escasa información de aquellos que, con sus objetivos, captaron los documentos visuales del Holocausto durante la II Guerra Mundial.

A finales de la década de los cuarenta, bajo Stalin y Rákosi, y durante toda la década de los cincuenta, la fotografía de orientación social ${ }^{18}$ fue relegada al nivel de lo que el Sistema consideraba "innecesario". Los sesenta cambiaron esta situación con fotógrafos que documentaron, desde una mirada crítica, nuevos conflictos y viejas injusticias sociales. Sándor Bojár, es un buen ejemplo de ello, aunque fueron los fotógrafos de prensa como Péter Korniss o Tamás Féner ${ }^{19}$, los que dominaron el momento con sus obras.

El Museo Etnográfico de Budapest atesora la mejor colección de fotografía etnográfica de Hungría, sin duda, una de las mejores de Europa. Desde sus inicios, la colección recopiló fotografías y negativos de producción húngara y extranjera, antiguos y contemporáneos. Se trata de imágenes captadas por miles de fotógrafos anónimos o que adquirieron el reconocimiento de sus coetáneos, y que nos informan sobre la historia social y cultural de la Hungría de los últimos 150 años. La Asociación Húngara de Fotógrafos organizó, desde 1958, los archivos del fondo, constituido por más de 100.000 imágenes y negativos, a los que se suma una colección de cámaras, equipos de laboratorio y documentos, como artículos críticos, catálogos fotográficos y otras publicaciones especializadas. Complementariamente, y desde 1991, el Museo archiva en sus fondos la obra de todos los fotógrafos que son o han sido figuras clave en la fotografía húngara. De este modo, junto con las fotografías de más estricta orientación etnográfica, puede consultarse la obra de fotógrafos de origen húngaro con reconocida fama mundial, como André Kertész, Gyula Halász (Brassai), György Kepes, Martin Munkácsy, o László Moholy-Nagy.

18 Los vínculos entre sociólogos, antropólogos, etnógrafos se evidencian en las obras publicadas por la Editorial Szolgálat és Írás Munkatársaság, Tiborc de Kata Kálmán, Zsigmond Móricz e Iván Boldizsár; Cifra nyomorúságában de Zoltán Szabó, Viharsarok de Géza Féja, Parasztságunk élete de Gyula Ortutay. Esta tradición continúa en la actualidad con fotoperiodistas como Tamás Féner, Hétköznapjáboz, editado con prólogo de Iván Vitányi.

19 Nuestro agradecimiento a Tamás Féner, Profesor de Fotografía en el Departamento de Antropología Cultural de la Universidad Eötvös Lóránd de Budapest, cuya trayectoria profesional es un brillante ejemplo del vínculo existente entre la fotografía social y el fotoperiodismo, y la mirada etnográfica en el contexto intelectual húngaro. 


\section{IMÁGENES EN MOVIMIENTO. EL FILM ETNOGRÁFICO}

La idea de llevar al campo de la investigación el registro fotográfico y fílmico surge ya a principios de siglo entre los etnógrafos húngaros ${ }^{20}$. Desde 1910, el Museo Etnográfico de Budapest completa con la filmación de danzas y fiestas populares, sus archivos de registros fotográficos y sonoros, tomados en el campo durante las investigaciones. Los primeros films etnográficos de los que tenemos constancia en Hungría son obra de Sándor Gönyey en 1927. Pero será durante toda la década de los años treinta -que consideraremos, sin duda, como la de inicio del film etnográfico en Hungría - cuando se produzcan las realizaciones, en $35 \mathrm{~mm}$, de Georges Höllering, de origen austríaco, y su film sobre Hortobágy; así como las películas de Pál Fejõs, rodadas en el Perú, Madagascar y Siam.

Por falta de subvenciones estatales, la mayoría de los investigadores autofinanciaban sus films, con la más o menos fundada esperanza de poderlos vender más tarde al Museo Etnográfico. En este contexto, la apuesta por la financiación del registro audiovisual que inició el Instituto Científico de Transilvania en 1941 comportó el gran desarrollo del film etnográfico en Hungría. De este modo, grupos de profesores y estudiantes rodaron metros y metros de película, no siempre con la misma calidad científica, en varias regiones de Transilvania. Desafortunadamente, la mayoría de este material desapareció después de la Segunda Guerra Mundial.

En 1940 László Keszi-Kovács, interesado por filmar los aspectos de la vida campesina en Hungría, inicia en Kolozsvár sus pioneras clases sobre cine etnográfico, que pasará a impartir después de la Guerra en el Departamento de Etnografía de la Universidad Eötvös Loránd de Budapest. Durante toda la década de los años cincuenta y sesenta, los documentales de la vida campesina se caracterizarán por dos marcadas orientaciones: la del entretenimiento, como las "cinenoticias", y la del interés etnográfico, como son las producciones fílmicas de dos etnógrafos de la época, Anna Raffay e István Szõts.

Será en los años sesenta cuando el film etnográfico cobre gran importancia, pero siempre con la planificación y el diseño de lo que, desde el

20 Como en el resto del contexto investigador europeo. Considérense las fotografías que, desde la década de 1870, captaban investigadores como E. H. Man, G. E. Dobson, M. V. Portman, C. Rogers, H. Seton-Karr, o R. Boreham entre los Andaman. Los registros de Alfred Cort Haddon y la expedición de Cambridge al Estrecho de Torres en 1898, o de Spencer entre los Aranda, en 1901 y 1902, y Rudolf Pöch en Nueva Guinea, entre 1904 y 1907. 
Museo Etnográfico, se consideraba científicamente relevante para ser filmado. Durante décadas, el Museo ha sido el auténtico y único motor del cine etnográfico en Hungría, financiando films de orientación clásica sobre la vida y costumbres en el campo. Aparte de algunas otras "cinenoticias", los verdaderos frutos de esta época son las películas de Lajos Boglár y György Martin, etnógrafos que sabían cómo aprovechar la relativa libertad económica que ahora se les ofrecía al rodar una película. Como declaraba, en 1986, Lajos Boglár: "Me ofrecieron unas posibilidades sin igual. Para los cineastas no será necesario que explique qué significa que cuando decía que necesitaba, digamos, unos 1200 metros para una película, me compraban 1200 metros. La podía 'extra-rodar'. Podía intentar distintos ángulos de registro, buscar las imágenes más adecuadas, hasta que sentí que podía hacer ver algo desde varios puntos de vista" ${ }^{21}$.

En 1968 se celebra por primera vez en Budapest el Festival de Películas Etnográficas, con la participación de realizadores húngaros y extranjeros. En la década de los setenta, podemos situar los comienzos de la antropología visual en Hungría con la aparición de realizadores de documentales de orientación antropológica como Vitézy, Darday y los hermanos Gulyás. La década de los ochenta será la de la institucionalización del cine etnográfico. En 1983 se crea la Subdivisión de Películas y Fotografías Etnográficas de la Asociación Etnográfica de Hungría, con la presidencia de Lajos Boglár y la secretaría de János Tari. En 1985 se inaugura el Estudio Etnográfico de Películas, en el marco del Museo Etnográfico. Desde el primer momento, el Estudio lleva a cabo la producción de films con una orientación diversa que abarca, tanto el propósito comunicacional, didáctico, educativo, de historia de la ciencia, como el valor documental, museológico y, en última instancia, patrimonial del propio registro. Aparte de la renovación y catalogación de las películas archivadas, el equipo del Estudio Etnográfico de Películas ha producido en la última década varios documentales propios. El director actual del estudio es János Tari, una figura de primer orden en la antropología visual húngara, y entre sus colaboradores se encuentran investigadores tan destacados como Judit Csorba. En la actualidad, la colección dispone de unos fondos con 136 películas catalogadas y otras 110 no editadas; la mayoría sobre danzas, ritos, costumbres y creencias populares, y elementos de la economía del campesinado, división del trabajo, trajes y artes tradicionales en Hungría ${ }^{22}$.

21 En su entrevista con István Antal 1986.

22 Es posible adquirir copias de estos films, así como de algunas de las fotografías de los Fondos del Museo Etnográfico de Budapest en httpll:www.hem.hu. 
LOS PROYECTOS, LOS INVESTIGADORES

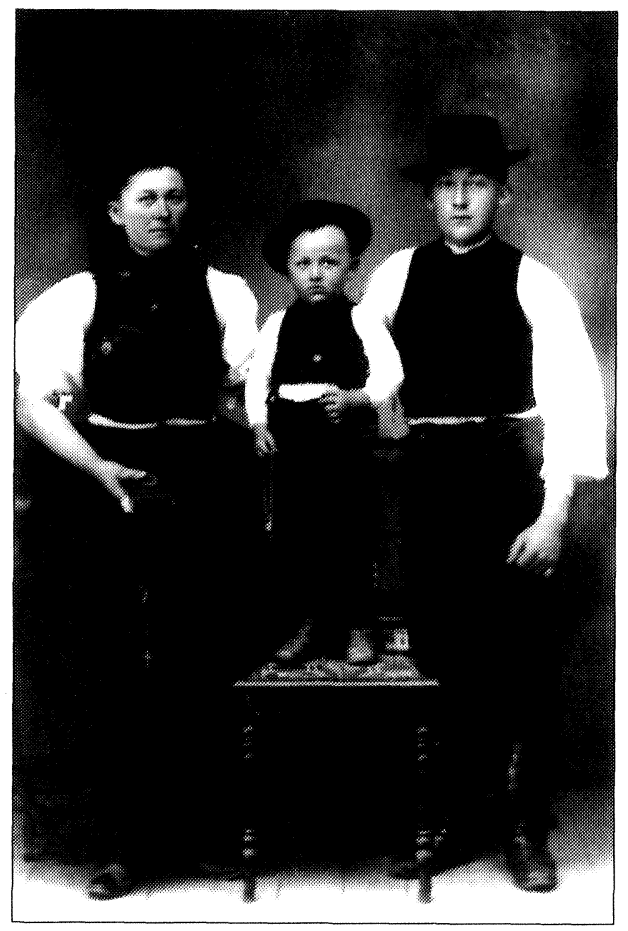

Si consideramos que la disciplina antropológica no alcanzará el reconocimiento universitario ${ }^{23}$ en Hungría hasta que en 1990 Lajos Boglár funde el primer Departamento de Antropología Cultural ${ }^{24}$, no será difícil entender la ausencia total de la antropología visual en cualquier discusión metodológica, en un panorama investigador históricamente centrado en la exhaustiva recolección etnográfica de imágenes bajo el patrocinio del Museo Etnográfico. Acontecimientos políticos y sociales, más allá del estricto terreno de la investigación, propiciaron este aislamiento académico e intelectual que, en el campo de la antropología, vino a romperse con la constitución de este primer departamento en la Universidad Eötvös Loránd de Budapest.

\section{FILM ETNOGRÁFICO}

Desde el primer momento, Lajos Boglár incorpora en su equipo docente a realizadores del nivel de János Tari o Judit Csorba, en el terreno del film y el vídeo, y a Tamás Féner en el de los estudios fotográficos. En 1993 Ernõ Kunt funda el Departamento de Antropología Visual y Cultural de la Universidad de Miskolc e inicia el que, hasta hoy, es el gran

23 Frente a la fecha de 1936-1938 en la que se "inaugura" la antropología visual como disciplina, con la tan citada investigación que Margaret Mead y Gregory Bateson llevaron a cabo en Bali para el Comité de Estudio de la Demencia Precoz.

24 Dentro del marco institucional de la Universidad Eötvös Loránd de Budapest y con el patrocinio económico de la Fundación Soros se inicia en 1990 el Programa de Estudios en Antropología Cultural que, dos años más tarde, con la aprobación de la Universidad, constituirá el Departamento de Antropología Cultural. 
proyecto de investigación visual en Hungría, el estudio global de las fotografías familiares entendidas como elementos cotidianos de la cultura material de los últimos 150 años. El panorama académico se completará con los estudios de antropología del Departamento de Comunicación de la Universidad de Pécs.

Siempre explico a los estudiantes que existe una noción en la etnografía que es la etnografía aplicada. Lo que por ejemplo hizo el representante colonial inglés en el interés de los colonizadores ingleses. Este era un etnógrafo aplicado, que observaba fenómenos para poder utilizar las leyes contra los colonizados. Frente a la etnografía aplicada, debemos hacer una etnografía adaptada. Es decir, adaptarnos siempre a lo que encontremos. Porque si partimos de la idea del mito, el rito y los fenómenos de la cultura tradicional, entonces simplemente no nos damos cuenta de lo que está pasando hoy en día (Boglár 1986).

Lajos Boglár empezó su trayectoria fílmica en la Colección de Películas del Museo Etnográfico de Budapest y durante años contribuyó de un modo decisivo al desarrollo y ampliación de sus fondos. Su película más famosa de esta etapa de films rodados en Hungría es Asszonyfarsang ( $E l$ Carnaval de las mujeres), de 1967, sobre el carnaval de mujeres de la villa de Mátraalmás. Pero las principales realizaciones como etnocineasta las ha llevado a cabo en sus investigaciones como amazonista en Brasil, Venezuela y la Guyana.

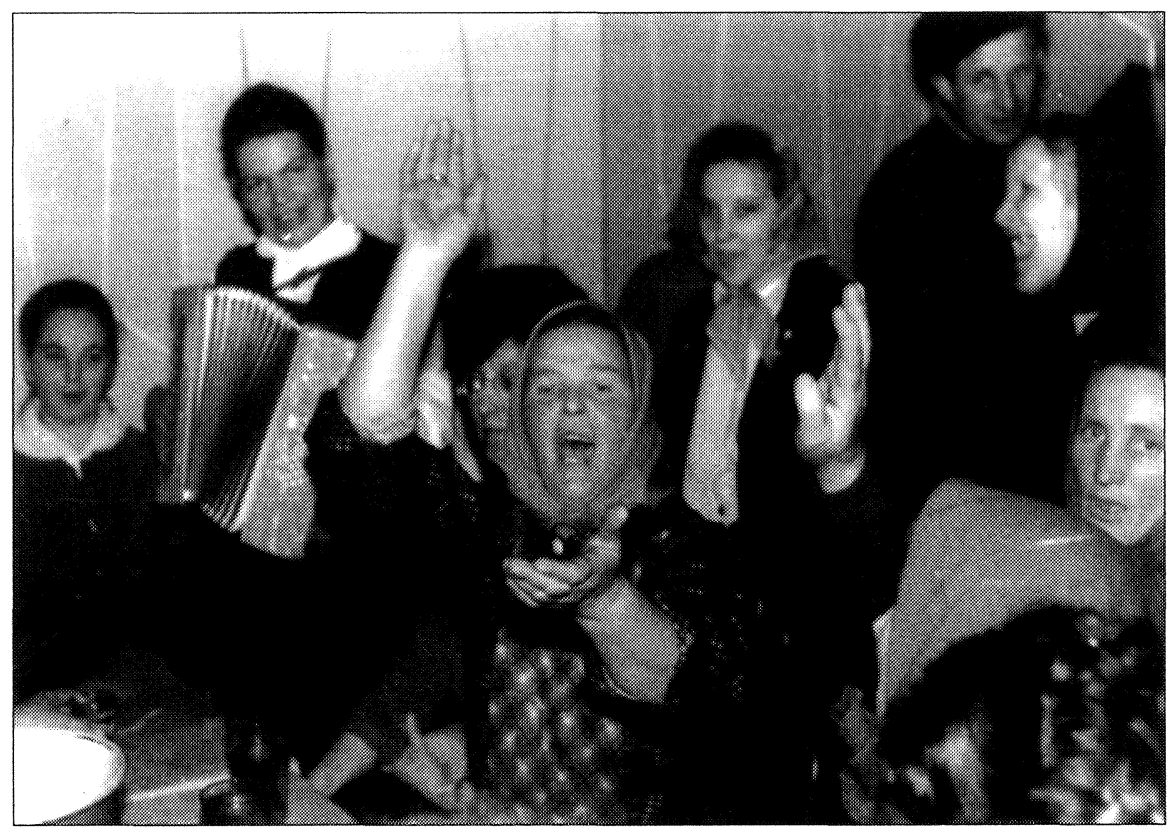


Boglár comenzó a interesarse por las comunidades indígenas de América Latina, desde el punto de vista de la antropología de emergencia, considerando que aquellos momentos eran los últimos para documentar una cultura al borde de la extinción, entregándose, de este modo a su grabación sistemática. Empezó su proyecto en Venezuela, entre los piaroa (19671968) con el método de "grabarlo todo, porque a priori no se puede establecer qué es lo importante" y en 1969 estrenó su película, A piaroák világa (El mundo de los Piaroas), en blanco y negro y con el sonido grabado en cintas magnetofónicas. Fruto de su investigación en Brasil entre los guaraní (1979-1985), son tres películas rodadas en el poblado de Prumirim de Boa Vista. En la actualidad, centra sus investigaciones ${ }^{25}$ en torno a una comunidad brasileña de descendientes de inmigrantes húngaros de principios de siglo, y su intento por recuperar las tradiciones folklóricas de la Hungría de sus antepasados.

Para este realizador, la convivencia con los informantes es el factor básico que determina el valor antropológico de un film, frente a la cada vez más frecuente investigación dominguera. Y en esta línea no sólo destaca como importante la fase de filmación en una comunidad, sino también el período anterior al rodaje de la película, y las posibilidades que ofrece para familiarizar a los informantes con la presencia del investigador y la cámara, que se completan, en el caso del vídeo, con las posibilidades del feed-back inmediato en una etapa posterior.

Resulta una constante en toda la filmografía de Lajos Boglár el papel de la ética en la investigación etnográfica, y la responsabilidad que el antropólogo necesariamente debe asumir frente a la comunidad que registra. En el caso de su film Asszonyfarsang, después de su proyección pública, las mujeres de Mátraalmás, que habían protagonizado la celebración del Carnaval en ese año, manifestaron a Boglár su temor por las amenazas recibidas por parte de algunos hombres que pasaron a tacharlas de mujeres fáciles e inmorales ${ }^{26}$. La propia comunidad guaraní de

25 Recientemente ha presentado en el Canal Duna de la televisión húngara el primer film sobre esta investigación.

26 Casi tan importante como la cinta en sí, resulta su historia de producción y rodaje, y la consideración de la presencia del antropólogo en el pueblo, durante y después del mismo. Según Katalin Jávor (1968), a quien agradecemos la colaboración prestada, la acusación de inmoralidad formulada a las mujeres estuvo presente desde la década de los cincuenta, paralelamente al cambio en la base económica de la región. A lo largo de los años, la estratificación del pueblo aumentó, generándose cada vez un mayor número de conflictos, incluso entre las propias mujeres. Asistir al Carnaval pasó a ser sinónimo de ponerse en situación de riesgo y ser objeto de chismorreo y habladurías. En 1967-1968, cuando Boglár filma su película, el rito había per- 
Prumirim de Boa Vista, después de muchos años de convivencia mutua le plantearon su intención de cobrar, hartos de que los blancos "se enriqueciesen" con sus imágenes. Una prueba más de que las relaciones interpersonales entre el antropólogo y sus informantes nunca son estables, y de la necesidad de adaptarse en cada investigación a la situación propia del momento, libre de apriorismos.

János Tari ${ }^{27}$ es un aténtico defensor del soporte fílmico frente a la opción del registro en vídeo. En la actualidad, los etnocineastas húngaros, que antes trabajaban con película, no pueden mantener el ritmo y asumen el empleo del vídeo, a pesar de comportar un lenguaje distinto al del film, como una solución técnica y presupuestaria necesaria. Una época, la del film etnográfico, se acaba, iniciándose la utilización masiva del vídeo. En este caso, la antropología visual húngara participa de la tónica común del contexto investigador mundial. En estas circunstancias, señala Tari, la enseñanza de la técnica cinematográfica se hace imprescindible, para asumir la responsabilidad que conlleva el manejo de la cámara ante nuestros informantes y los futuros espectadores, investigadores, de nuestras imágenes. Ahora, cuando constantemente manejamos conceptos como

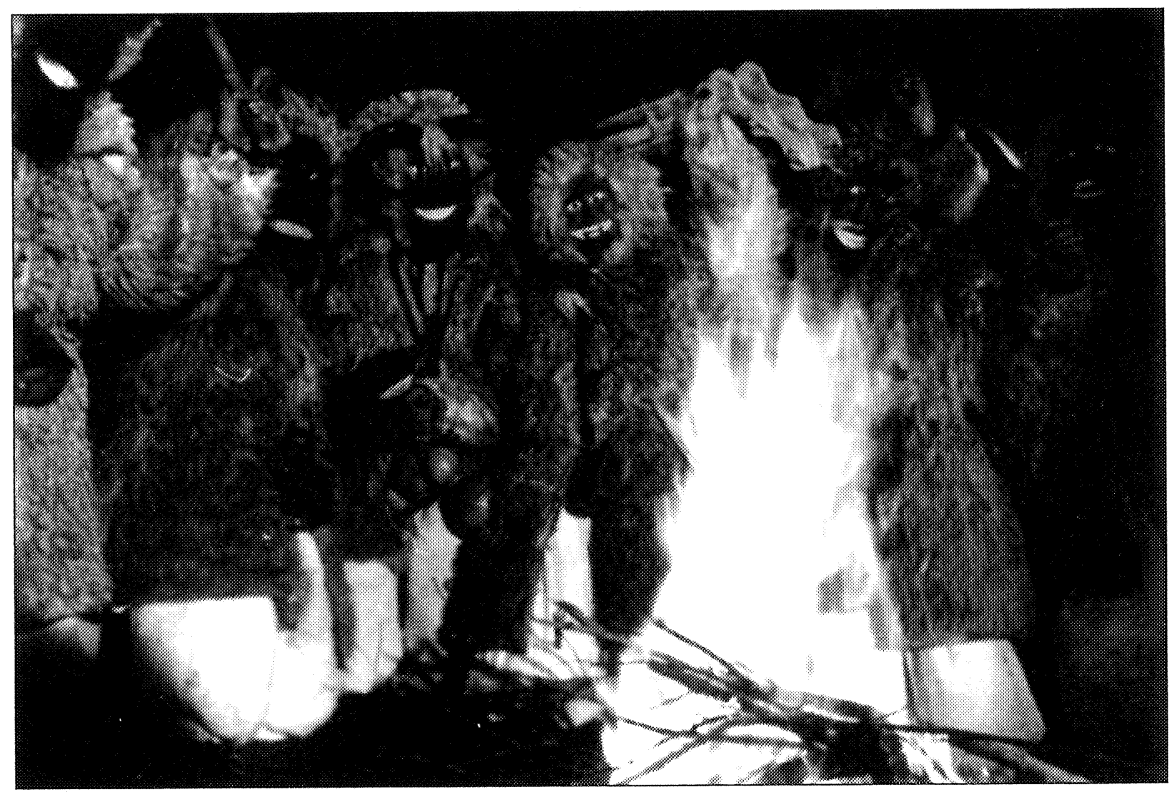

dido ya gran parte de su contenido tradicional, y eran muchas las mujeres que se abstenían de participar en él. Actuar delante de la cámara de un antropólogo, y más si se trataba de un hombre, contribuyó a dinamitar la situación.

27 Ha sido jurado del festival de Film Etnográfico de Göttingen en 1998. 
el de multiculturalidad, podemos, a través de los films etnográficos, participar en otras culturas y acercarnos al "otro", y si no nos identificamos con él, cuando menos aprenderemos a conocerle.

Zoltán Füredi, discípulo de Lajos Boglár y János Tari, es un investigador de reconocida trayectoria en el panorama de la antropología visual húngara actual, como especialista en Filología Mongol y profesor en el mismo Departamento de Antropología Cultural, centra su investigación audiovisual, desde principios de los noventa, tanto en Hungría como en Mongolia.

En sus investigaciones en Hungría ha estudiado elementos de cultura tradicional y su relectura desde el fenómeno del turismo, centrándose concretamente en las hermandades de los busos de Mohács en la celebración del Carnaval.

Desde 1993 investiga en una comunidad de hombres y mujeres sin techo que sobrevive en el distrito lujoso de las colinas de Buda. Fruto de esta investigación es la realización de dos films ${ }^{28}$, donde destaca el contraste entre los elementos de subsistencia que documenta, frente a las fiestas de las embajadas vecinas. Actualmente, está rodando una película en Répáshuta, un pueblo situado al norte de Hungría, sobre la vida de una comunidad de carboneros y leñadores de la zona.

\section{FOTOGRAFÍA ETNOGRÁFICA}

Si hubiera que establecer la figura clave en el desarrollo de la investigación visual en la etnografía húngara pensaríamos en Ernõ Kunt ${ }^{29}$. La obra de Kunt es sin duda la de un teórico de primer orden en el campo de la investigación etnográfica a través de la imagen, del que desgraciadamente poco se conoce fuera del contexto intelectual húngaro. Fallecido en 1994, después de fundar y dirigir en la ciudad de Miskolc ${ }^{30}$ el primer

28 La primera película titulada Vágatlanul es realmente una película de 13 minutos, sin editar, que en 1906 fue galardonada por el Festival Internacional de Documentales Amateurs de Bitola, Macedonia. Su film Villanegyed, que presenta la vida y los conflictos cotidianos de esta comunidad, ha sido galardonado este año en el Festival Internacional de Películas Etnográficas de Göttingen.

29 Desde los años noventa impartió sus lecciones de antropología visual en la Universidad Eötvös Loránd de Budapest, compaginándolas con su actividad como docente en la Institución Jung de Suiza y en la Philips University en Marburg.

30 La situación de recesión económica, ante el cierre de las fábricas de industria pesada, por la que en la actualidad atraviesa Miskolc, auténtica ciudad-motor industrial de Hungría, afectó a los planes de estudio de su Universidad Técnica, rediseñando 
Departamento de Antropología Visual de Hungría, centró sus investigaciones en la interpretación de las fotografías familiares entendidas como objetos cotidianos de la cultura material, dotados de contenido psicológico y social. Su análisis en torno al uso de la fotografía en las comunidades tradicionales redimensionó los estudios campesinos, revelando mecanismos de adaptación e innovación en su capacidad para aprovechar los resortes comunicacionales y autorreflexivos que comporta el uso social de la fotografía. Desde esta perspectiva, analizó los elementos del imaginario campesino representados en las imágenes familiares y en qué medida la fotografía privada contribuyó a la redacción de la historia pública común. En esta línea, a través del estudio de las fotografías familiares, siguió no sólo los acontecimientos más relevantes de la biografía de los retratados, sino también el cambio dinámico en la noción de familia y su integración en una sociedad cambiante. El hecho de que, en la mayoría de los casos estudiados, fuesen los propios campesinos los que tomaban sus fotografías, sin recurrir a reconstrucciones de estudio, nos proporciona en la actualidad, de un modo directo, datos adicionales sobre distintos grupos étnicos y su cultura material.

Durante sus investigaciones de campo, Ernõ Kunt analizó el significado cognitivo y emocional de las fotografías enmarcadas que los campesinos colgaban de la pared; imágenes que reforzaban diariamente su autoconfianza y sentimiento de identidad y pertenencia a la comunidad. Cuadros, a menudo auténticos collages de imágenes, que constituían soportes para la memoria familiar, mostrando los cambios de los miembros retratados a lo largo de los años. La pared de la que colgaban las fotografías se revela como un gran marco que unía, a través de las imágenes, a los miembros de la familia con sus presencias y sus ausencias, tanto a los vivos como a los muertos, trazando la biografía social y personal de la familia. Estos cuadros señalaban los espacios simbólicos del hogar, como la cabecera de la cama del padre, incorporando en los marcos elementos decorativos del estilo típico de la región. El proceso de elaboración de los marcos demuestra la importancia de las fotografías para sus propietarios y la total integración en sus vidas. Es el caso de los soldados que, desde el frente en la I Guerra Mundial, tallaban en sus ratos libres el marco para la fotografía de la novia o de la familia, estableciendo un vínculo simbólico con los allegados, más allá de la distancia y de los acontecimientos.

A la muerte de Ernõ Kunt, su discípulo András Bán, crítico de arte y profesor de imagen en el mismo Departamento, ha sido el continuador

su orientación global con incorporaciones como la del Departamento de Antropología Visual y Cultural. 
de la investigación sobre fotografía familiar. Bán participa, desde 1982, en el proyecto del archivo de imágenes fotográficas. Desde el primer momento este archivo nació vinculado al desarrollo de la investigación de Kunt, con el objetivo de compilar y dotar de significado las fotografías de familia que, a través de cartas o entrevistas directas, se recibían en el Departamento $^{31}$. La esfera de lo privado esconde miles de fotografías y con ellas multitud de historias particulares que nunca o muy superficialmente han sido objeto del interés de la investigación etnográfica. La aportación de Bán al proyecto de la fotografía familiar se centra en el intento por verbalizar estas imágenes con los comentarios, los recuerdos, las impresiones de los miembros de cada familia.

En 1979 la Academia Húngara de Ciencias y el Consejo Americano de Sociedades de Estudio inició un proyecto de investigación sobre la preservación de la identidad nacional entre los descendientes de los emigrantes húngaros en el estado de Indiana ${ }^{32}$. La investigación abarcaba consideraciones de carácter histórico, literario, lingüístico y, por supuesto, etnográfico.

En 1984, y después de cuatro años de diseño del proyecto tanto en Estados Unidos como en Hungría, Zoltán Fejõs, Péter Niedermüller y Mihály Hoppál iniciaron en Indiana su trabajo de campo sobre la identidad étnica entre los descendientes de los emigrantes húngaros. Los investigadores comprobaron cómo durante las entrevistas de las historias de vida los informantes recurrían frecuentemente a las páginas de sus albumes de fotografías para "recordar mejor" los acontecimientos de su historia familiar. Desde ese momento, Mihály Hoppál consideró imprescindible el estudio de estas imágenes y el uso de su poder elicitador de la memoria en las entrevistas con los informantes.

Como la emigración húngara llegó a Estados Unidos en tres distintas oleadas durante este siglo, las fotografías objeto de estudio correspondían a generaciones diversas y con distintos criterios a la hora de considerar un acontecimiento familiar como relevante y, por tanto, digno de ser fotografiado. Hoppál comprobó cómo se mantienen en estas imágenes, a través de las generaciones, lugares comunes siempre fotografiados: bodas, funerales o visitas de familiares de Hungría.

31 Para más información es posible consultar algunas reproducciones de estas cartas en el artículo de András Bán 1989.

32 Identity Preservation throught Traditionalizing. A Comparative Study in Modern Hungary and the United States, Zoltán Fejõs, del Museo Etnográfico de Budapest, Péter Niedermüller y Mihály Hoppál del Instituto Etnográfico de la Academia Húngara de Ciencias (con la organización de Linda Dégh desde los Estados Unidos y de Tamás Hofer desde Hungría) 
A través de sus fotografías, se mantiene viva la memoria del pasado familiar y se sitúan los orígenes y las raíces. Incluso el rito de observarlas junto a la nueva generación ofrece la posibilidad de mantener la tradición, introduciendo a los jóvenes en la historia de la familia, perpetuando un distintivo étnico diferencial ${ }^{33}$ desde el imaginario común en torno a un pequeño país a miles de kilómetros.

Bien podría ser esta la conclusión de nuestras páginas: cómo la fotografía y el film etnográfico han tenido parte en la construcción de la identidad nacional de Hungría.

\section{BIBLIOGRAFÍA}

Albertini, Béla, 1989: "A szociofotó tegnap és ma", en Mihály Gara (ed.), A fotográfia hónapja, Budapest: Magyar Fotómûvészetek Szövetsége. Szabad Tér Kiadó.

ANTAL, István, 1986: "Beszélgetés Boglár Lajos néprajkutatóval", en Péter Forgács (ed.), Mozgó Film/2, Budapest: Balázs Béla Filmstúdió.

BÁN, András, 1989: "Lapok a családi albumból», en Mihály Gara (ed.), op. cit.

CATÁlogo, 1981: Tény-Kép. (Historia de la fotografía húngara, 1840-1981. Mûcsranok, Galería de Arte, Budapest, 19 de diciembre de 1981-31 de enero de 1982).

Colin, Ford, 1989: "A magyar kapcsolat", en Mihály Gara (ed.), op. cit.

GuARNÉ, Blai, 1997: "Comunicación visual a través de la imágenes", en Cultura e identidad cultural. Introducción a la antropologia, Barcelona: Ediciones Bardenas.

Hoppál, Mihály, 1989: "Family Photography of the American-Hungarians", en Bild-KundeVolks-Kunde, Miskolc: Hermann Ottó Múzeum.

JÁvor, Katalin, 1968: Asszonyfarsang Mátraalmáson, Budapest: Népi Kultúra-Népi Társadalom II-III. Akadémiai Kiadó.

KunT, Ernõ, 1992: "Approaches in Photo Antrophology - A case of study from Hungary", Ethnographica et Folkrolistica Carpathica, 7-8, II. Kossuth Lajos Tudományegyetem. MikLós, Pál, 1989: "Az elsõ százötven év", en Mihály Gara (ed.), op. cit.

SIPOS, Júlia, 1996: "Mintha mindenki japán turista volna. Beszélgetés Tari Jánossal”, Filmvilág (julio).

TARI, János, s. a.: Introducción al Estudio Etnográfico de Películas. http $\backslash:$ www.hem.hu TÒRY, Klára, 1989: "A magyaros stílus", en Mihály Gara (ed.), op. cit.

VV. AA, 1998.: Photography and Anthropology, Budapest: Nemzeti Kulturális Alap.

33 En palabras de Mihály Hoppál (1992): «Los gestos, los bailes, las canciones y las comidas sirven como señales de distinción étnica". Estas diferencias aparecen en las fotografías y, a través de ellas, reinterpretamos la realidad, convirtiendo sus imágenes en símbolos de la identidad étnica. 
El artículo repasa la historia de la fotografía etnográfica húngara, exponiendo las diferentes escuelas — como el denominado aestilo húngaro" -, instituciones y fotógrafos que, desde un punto de vista cada vez más antropológico, han recogido en imágenes los distintos aspectos de la cultura de ese país. Se analizan también los últimos proyectos audiovisuales, fílmicos y fotográficos, llevados a cabo por los más prestigiosos investigadores en antropología visual en los centros universitarios de Miskolc y Budapest.

The author reviews the history of ethnographic photography in Hungary: the different schools - such as the so-calles "Hungarian style -, institutions and photographers that from an ever more anthropological vantage point have visually recorded the multifarious aspects of the country's culture. In addition, the author discusses the latest projects -in photography as well as in film - carried out by the most prestigious researchers in visual anthropology at the universities of Miskoic and Budapest. 